[溶接学会論文集 第 29 巻 第 3 号 p. 139-145 (2011)]

\title{
溶融亜鉛めっき鉄筋の半自動アーク溶接時における シールドガスおよび電極ワイヤの影響*
}

\author{
村上 和美 $*$, 兼松 秀行***, 田中学 $* * * *$, 中田 一博**** \\ Effect of Shielding Gas and Electrode Wire on Weldability of Hot Dip Galvanizing Rebar \\ by Semi-automatic Arc Welding* \\ by MURAKAMI Kazumi**, KANEMATU Hideyuki***, TANAKA Manabu**** and NAKATA Kazuhiro****

\begin{abstract}
This paper deals with the welding properties of semi-automatic arc welding for hot dip galvanizing rebar to discuss the applicability of hot dip galvanizing steel to concrete rebar. The concrete rebar has many projection points to assure its adhesive property with concrete. The influence of these projections at the flare groove joint arrangement on the weldability of semi-automatic arc welding has been mainly investigated. As a result, the suitable combination of shielding gas and electrode wire on flare groove joint which shows less cavity formation and high joint shear strength has been made clear.
\end{abstract}

Key Words: Hot Dip Galvanizing, Steel bars for concrete reinforcement, semi-automatic arc welding, Cavity

1. 緒言

溶融亜鉛めっき鋼板の溶接に際しては，亜鉛めっき層か ら発生する亜鉛蒸気がブローホールやピットおよびスパッ 夕を発生させることが知られている ${ }^{1,2)}$.このため, 一般的 な亜鉛めっき鋼板の溶接ではピットやブローホールの発生 を抑制する幾つかの溶接施工方法が提案されており，例え ば，溶接施工前に溶融亜鉛めっき層を機械的に除去する方 法2)，アークのクリーニング作用によって亜鉛めっき層を除 去する方法 ${ }^{3}$ やパルスマグアーク溶接の適用 ${ }^{4}$, 5)などがある.

しかし，溶融要鉛めっきされた鉄筋コンクリート用棒鋼 （溶融亜鉛めっき鉄筋）のアーク溶接に関する報告はこれ までほとんど無い. 著者らは, 被覆アーク溶接法による溶 融业鉛めっき鉄筋のフレアー溶接継手に関して, 異形断面 を有する溶融亜鉛めっき鉄筋の継手配置をルートギャップ が得られるようにすることで, 溶接ビード内への亜鉛蒸気 の巻き込みを少なくし, 空洞等の気孔欠陥の発生を抑制で きることを示しだ). 一方, 半自動アーク溶接は被覆アーク 溶接に比して高溶着量で, かつ溶接速度が速いために溶接 能率が高いことが知られている。一般的な溶融亜鉛めっき 鋼板の溶接では溶接性改善のために, 溶接棒, 溶接ワイ ヤ，溶接機および使用ガス等のさまざまな検討がなされて

\begin{tabular}{rlrl}
\hline *受付日 & 平成22年12月9日 & 受理日 平成23年 7月 6日 \\
$* *$ 正 員 & $\begin{array}{l}\text { 三重県工業研究所 Member, Mie Prefecture Industrial } \\
\text { Research Institute }\end{array}$ \\
& 鈴鹿工業高等専門学校 Dept.MS \& E,Suzuka \\
& National College of Technology \\
****正 員 & $\begin{array}{l}\text { 大阪大学接合科学研究所 Member, Joining and } \\
\text { Welding Research Institute Osaka University }\end{array}$
\end{tabular}

きている．特に自動車産業を中心に半自動アーク溶接に関 する多くの提案がなされている.ところが，建設現場では 電源やガスの供給等, 設備的な問題が大きく, 半自動アー ク溶接はほとんど用いられていないのが現状である。しか しながら，建設現場において作業条件（高層階でない場 合）が揃えば，その適用の可能性は皆無とは言えない。そ こで，半自動アーク溶接に注目し，半自動アーク溶接にお ける溶融亜鉛めっき鉄筋の溶接継手の形成のしやすさや溶 接作業性並びに溶接欠陥および継手強度などの継手特性を 明らかにするためにシールドガスおよび電極ワイヤが異な る半自動アーク溶接を用いて, 継手配置や溶接条件などの 影響を検討した。そして半自動アーク溶接の溶融亜鉛めっ き鉄筋溶接への適用性を評価した。

\section{2. 使用材料および実験方法}

\section{1 溶融亜鉛めっき鉄筋}

試験片は鉄筋コンクリート用棒鋼（異形棒鋼，JIS G 3112 材料規格 SD295A D19）を，それぞれ $500 \mathrm{~mm}$ に切断し， $450 \pm 5^{\circ} \mathrm{C}$ の溶融亜鉛めっき浴に一定時間（3〜 4 min）浸漬 して, めっきを行った. めっき厚さは平均 $60 \mu \mathrm{m}$ とした.

\section{2 溶接法および電極ワイヤ}

本研究では，溶融亜鉛めっき鋼板での溶接が良好とされ ている幾つかのシールドガスと電極ワイヤの組み合わせ7, 8) を選択し，それぞれの条件で溶接を行ない，適用の可能性 を検討した. Table 1 に用いた溶接ワイヤとアーク溶接法の 組み合わせを示す. YGW 12, YGW14 およびYFW-C50 は，いずれも炭酸ガスアーク溶接用ワイヤであり，YGW12 
は軟鋼用ソリッドワイヤ, YGW14 は溶融亜鉛めっき鋼板用 ソリッドワイヤ，YFW-C50 は溶融亜鉛めっき鋼板用フラッ クコアードワイヤであり，極性が正極性で用いられる。ま た，YGW17 およびYFW-S50GBも同じく溶融亜鉛めっき鋼 板用であるが，YGW17 はシールドガスにアルゴン＋炭酸ガ スを用いるマグアーク溶接用ワイヤであり，YFW-S50GB はセルフシールド溶接用でフラックスコアードワイヤであ る.それぞれのワイヤの組成を Table 2 に示す.いずれも市 販のものである、鉄筋継手配置は, 前報のの結果に基づい て, ルート間隔がない鉄筋配置 $\mathrm{A}$ とルート間隔が確保でき る鉄筋配置 B の 2 つ鉄筋配置とした. Fig. 1 にその模式 図を示す。なお，被覆アーク溶接では鉄筋配置 B が良好な

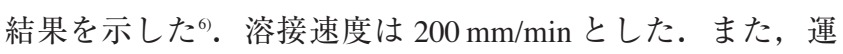
棒法はストレートとし, 前進溶接により, 保持角は $80^{\circ}$ と した。なお， ワイヤ突き出し長さは 10〜20 $\mathrm{mm}$ とし，シー ルドガスの流量は $20 \mathrm{~L} / \mathrm{min}$ とした。これらの条件下で溶接 電流を変化させた。

\section{3. 結果および考察}

\section{1 溶接継手形成}

\subsection{1 炭酸ガスアーク溶接}

(1) 軟鋼用ワイヤ（YGW12）

Fig. 2 に軟鋼用ワイヤ（YGW12）で炭酸ガスアーク溶接 を行った継手断面マクロ写真を示す. 電流值を鉄筋配置 $\mathrm{A}$

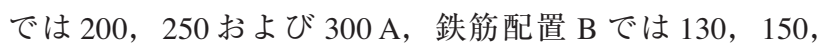

Table 1 Combinations of electrode wire, shielding gas and polarity of semi-automatic arc welding.

\begin{tabular}{|l|c|c|c|c|c|}
\hline \multicolumn{1}{|c|}{ Welding process } & \multicolumn{3}{|c|}{$\mathrm{CO}_{2}$ are welding } & $\begin{array}{c}\text { MAG arc } \\
\text { welding }\end{array}$ & $\begin{array}{c}\text { Self-shielded } \\
\text { arc welding }\end{array}$ \\
\hline Electrode wire standard & YGW12 & YGW14 & YFW-C50 & YGW17 & YFW-S50GB \\
\hline Classification & $\begin{array}{c}\text { Solid wire for } \\
\text { mild steel }\end{array}$ & Solid wire & Flux cored wire & Solid wire & Flux cored wire \\
\hline Shielding gas & $\mathrm{CO}_{2}$ & $\mathrm{CO}_{2}$ & $\mathrm{CO}_{2}$ & $\mathrm{Ar}+20 \% \mathrm{CO}_{2}$ & Non-gas \\
\hline Polarity & $\mathrm{DCEP}$ & DCEP & DCEN & DCEP & DCEN \\
\hline
\end{tabular}

Table 2 Chemical composition of weld metal.

\begin{tabular}{|c|c|c|c|c|c|}
\hline \multirow{2}{*}{$\begin{array}{c}\text { Electrode } \\
\text { wire }\end{array}$} & \multicolumn{5}{|c|}{ Chemical composition (mass\%) } \\
\cline { 2 - 6 } & $\mathrm{C}$ & $\mathrm{Si}$ & $\mathrm{Mn}$ & $\mathrm{P}$ & $\mathrm{S}$ \\
\hline YGW12 & 0.07 & 0.50 & 1.05 & 0.012 & 0.016 \\
\hline YGW14 & 0.08 & 0.28 & 1.31 & 0.009 & 0.011 \\
\hline YFG-C50 & 0.10 & 0.40 & 1.55 & 0.025 & 0.012 \\
\hline YGW17 & 0.09 & 0.35 & 1.52 & 0.013 & 0.009 \\
\hline YFW-50GB & 0.21 & 0.35 & 0.65 & 0.010 & 0.004 \\
\hline
\end{tabular}

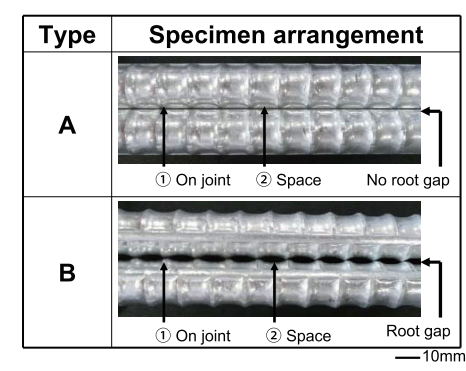

Fig. 1 Arrangement patterns used for flare joint of concrete rebar.
200 および $250 \mathrm{~A}$ で行った。断面マクロ観察は鉄筋相互の 「ふし」が重なる箇所（On joint； Fig. 1中1)）と「ふし」 が重らない箇所（Space； Fig. 1 中(2)）に分けて観察を行っ た。被覆アーク溶接において問題となった亜鉛蒸気の溶接 ビード内への巻き达みによる空洞形成は，いずれの試料で も認められなかった。主な要因としては, 溶接時のアーク 力が強いため, 亜鉛めっきより発生した亜鉛が蒸発し，溶 接ビード内に取り込まれなくなったものと考えられる。一 方，ルート間隔が大きい鉄筋配置 $\mathrm{B}$ では電流值が $250 \mathrm{~A}$ に なると, 著しい溶落ちが認められた.

Fig. 3 に軟鋼用ワイヤ（YGW12）を用いて炭酸ガスアー ク溶接を行った試料の継手引張せん断荷重を示す.ビード 長さについて, 日本建築学会建築工事標準仕様書・同解説 では必要定着長さを鉄筋の公称直径の10倍としているが, ビード長さを10倍とした試料は，すべて母材破断をするこ とから, 本研究でのビード長さはすべて公称直径の 5 倍の 長さとした。なお，著しい溶け落ちを呈した鉄筋配置 B, 電流值 $250 \mathrm{~A}$ の試料は除いている。この図から, 鉄筋配置

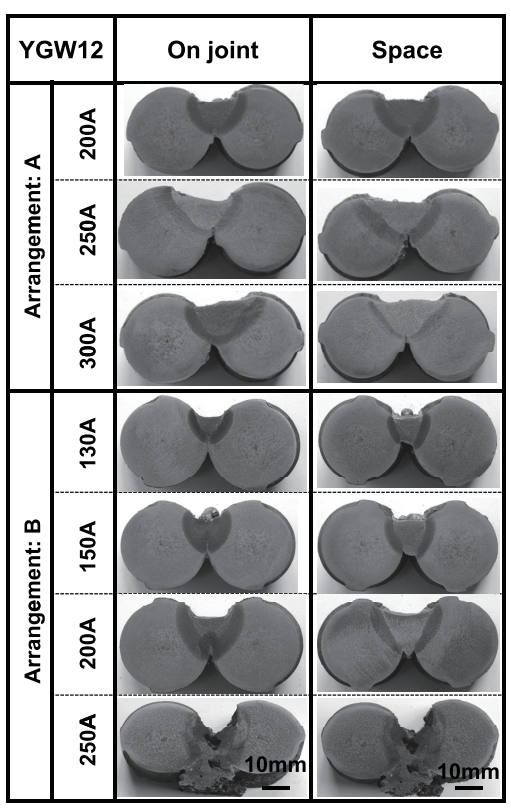

Fig. 2 Cross sectional macrostructures of flare joint of concrete rebar by semi-automatic $\mathrm{CO}_{2}$ arc welding with YGW12 electrode wire.

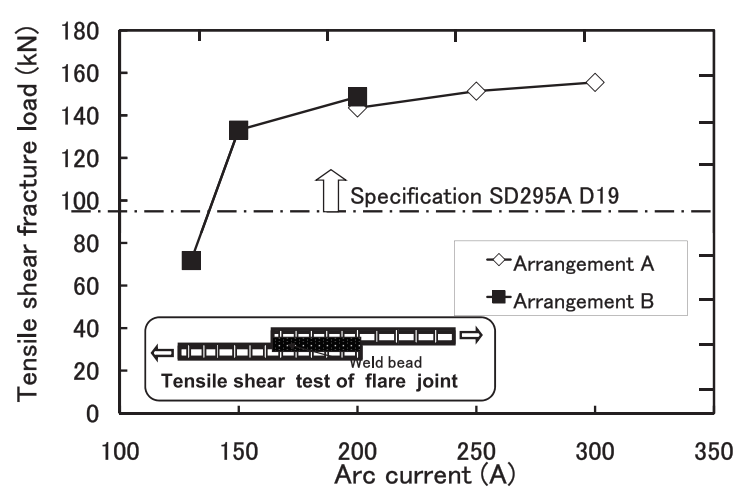

Fig. 3 Relation between tensile shear fracture strength and arc current at different arrangements by semi-automatic $\mathrm{CO}_{2}$ arc welding with YGW12. 
B, 電流值 $130 \mathrm{~A}$ 以外の引張せん断荷重は鉄筋継手に必要と される荷重 $\mathrm{P}$ (本研究では $100 \mathrm{kN}$ とした）を越えることが 確認された. 電流值の増加とともに引張せん断荷重が増加 するのは, 溶接ビード断面積の増加に伴うものである.

なお，荷重 P は次式 (1) で表される.

$$
P=\frac{\pi d^{2}}{4} \sigma \times \frac{L_{2}}{L_{1}}
$$

$\mathrm{P}$ ：継手に必要とされる強度 $(\mathrm{N}), \sigma$ ：引張強さ $\left(\mathrm{N} / \mathrm{mm}^{2}\right)$ $\mathrm{L}_{1}$ : 規格ビード長さ $(\mathrm{mm}), \mathrm{L}_{2}$ : 本研究での有効ビード長 $(\mathrm{mm})$

本研究では, JIS G 3112 鉄筋コンクリート用棒鋼 種類の 記号：SD295A，呼び寸法：D19 の鉄筋を用いた。この鉄筋 の公称直径 $\mathrm{d}$ は $19.10 \mathrm{~mm}$, 引張強さの規格值 $\sigma$ は $600 \mathrm{~N} / \mathrm{mm}^{2}$ である. なお, 溶接終始端の溶接長を $2 \mathrm{~d}$ として $\mathrm{L}_{1}$ は $8 \mathrm{~d}$ とし， $\mathrm{L}_{2}$ は $5 \mathrm{~d}$ とした。これらの数值を式 (1) に代 入したところ, $\mathrm{P}=90473(\mathrm{~N})$ となったため, 本研究の継手 に必要とされる強度 $\mathrm{P}$ を $100 \mathrm{kN}$ とした。

(2) 亜鉛めっき用ワイヤ（YGW14）

Fig. 4 に亜鉛めっき用ワイヤ（YGW14）を用いた炭酸ガ スアーク溶接継手の断面マクロ観察結果を示す. 溶接条件 等は軟鋼用ワイヤ (YGW12) と同様である。このワイヤ は，溶着金属の粘性を高めて亜鉛蒸気を溶融金属内にとじ 达めるタイプである.このため, ルート間隔が小さく，電 流值が高い場合はスパッ夕の多量発生があるとされている 7). 前報の被覆アーク溶接の結果( ${ }^{\circ}$ とは異なり，ルート間隔 のない鉄筋配置 $\mathrm{A}$ でも断面マク口観察結果は良好であっ た。一方, 被覆アーク溶接では良い結果が得られたルート 間隔が確保できる鉄筋配置 B では，スパッタが多く発生 し，また，断面マク口観察結果から，融合不良（図中矢

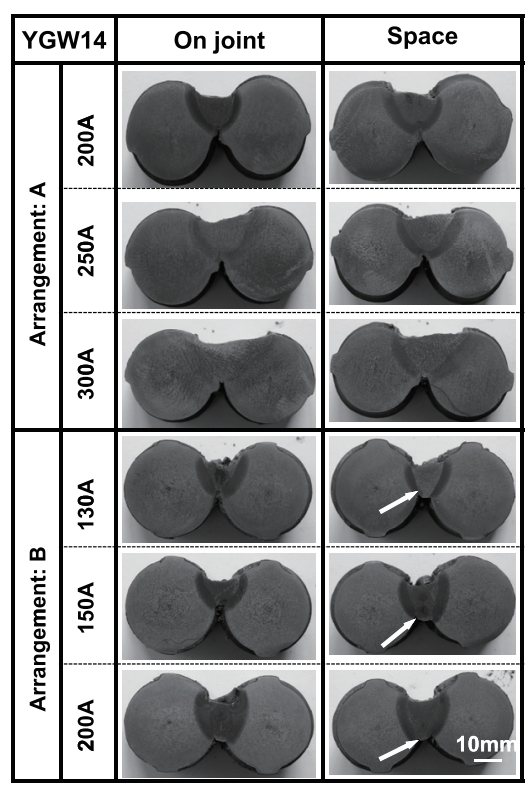

Fig. 4 Cross sectional macrostructures of flare joint of concrete rebar by semi-automatic $\mathrm{CO}_{2}$ arc welding with YGW14 wire; white arrow shows lack of fusion.
印）が認められた。半自動溶接で使用されるワイヤの多く は線径が $1.2 \mathrm{~mm}$ と細いため, ワイヤ先端が鉄筋相互の隙間 に入り込み，アークが安定せず，ルート部での融合不良が 発生すると考えられる。一方，前報で報告した被覆アーク 溶接では溶接棒の線径が $3.2 \mathrm{~mm}$ および $4.5 \mathrm{~mm}$ 程度と太い ことと，アークカが小さいため，溶落ちなどの現象はほと んど見られなかった。以上の結果，溶着金属の粘性を高め て亜鉛蒸気を溶融金属内にとじ达めるタイプのワイヤ

（YGW14）を用いた亜鉛めっき鉄筋の溶接では，良好な継 手を得るためにはルート間隔が小さい鉄筋配置 A が適して いることがわかった。

(3) 亜鉛めっき用ワイヤ（YFW-C50）

市販の亜鉛めっき用フラックスコアードワイヤ（YFWC50）を用いた炭酸ガスアーク溶接継手の断面マクロ写真 を Fig. 5 に示す。溶接条件等は軟鋼用ワイヤ（YGW12）と 同様である。このワイヤは, 亜鉛めっき用ワイヤ （YGW14）とは逆に溶着金属の粘性を下げて亜鉛蒸気の離 脱を促進させるタイプのワイヤである ${ }^{8)}$.また，正極性で溶 接を行なう特徴もある. Fig. 5 の鉄筋配置 A では，ビード 割れ，ルート割れなどの溶接欠陷は確認されなかった。し かし，鉄筋配置 B では，電流值が低い試料（130 A および $150 \mathrm{~A}$ ）に融合不良（図中矢印）が認められた。これらのこ とから，溶着金属の粘性を下げて亜鉛蒸気の離脱を促進さ せる夕イプのワイヤを用いた亜鉛めっき鉄筋の溶接では, 継手形状はルート間隔が小さい鉄筋配置 A が適しているこ とが分かった。

\subsection{2 マグアーク溶接（亜鉛めっき用ワイヤ YGW17）}

Fig. 6 に亜鉛めっき用ワイヤ（YGW17）によるマグアー ク溶接継手の断面マクロ写真を示す．溶接条件等は軟鋼用

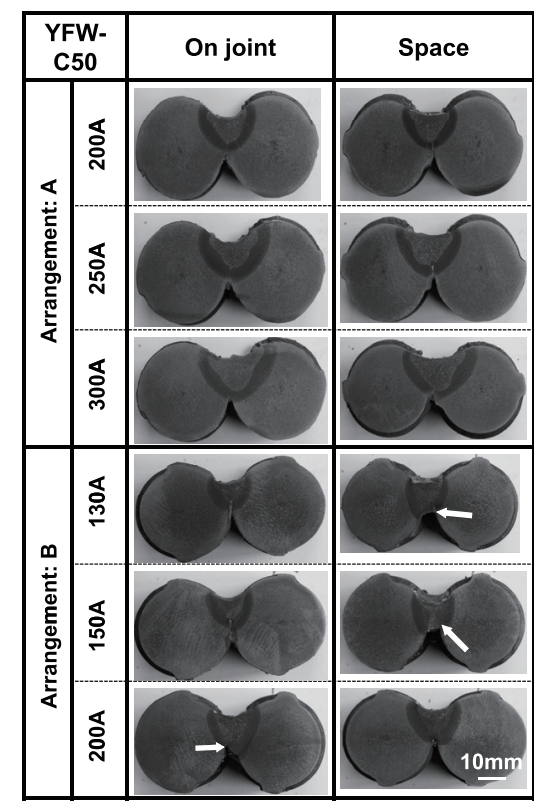

Fig. 5 Cross sectional macrostructures of flare joint of concrete rebar by semi-automatic $\mathrm{CO}_{2}$ arc welding with YFW-C50 wire; white arrow shows lack of fusion. 
ワイヤ (YGW12) と同様である。このワイヤは，溶接作業 性を重視したソリッドワイヤである9. また。シールドガス には $\mathrm{Ar}-20 \% \mathrm{CO}_{2}$ 混合ガスを用いた。シールドガスに安定な アルゴンを用いることによって, 炭酸ガスアーク溶接で発 生する大粒スパッ夕を解消し，スプレー溶滴移行を可能と することを目的とするワイヤで带鉛蒸気をとじ込める型に 分類される9. 鉄筋配置 $\mathrm{A}$ の場合, 電流值 $300 \mathrm{~A}$ では著しい 溶落ちが発生した。一般的に, 炭酸ガスアーク溶接に比し て，マグアーク溶接ではアークの集中性が良く，アーク力 も強くなる傾向にあり, さらに, 鉄筋では表面形状の変化 が大きく，アーク直下に溶融池が安定して形成され難くな

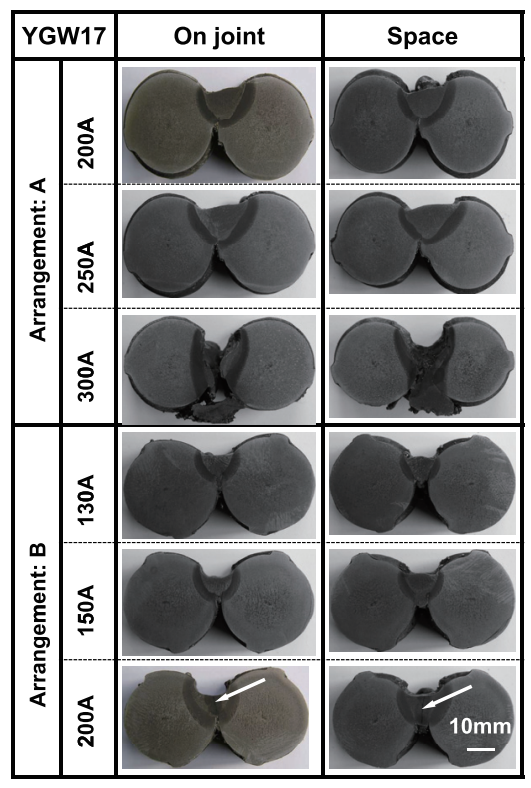

Fig. 6 Cross sectional macrostructures of flare joint of concrete rebar by MAG arc welding with YGW17 wire; white arrow shows crack in weld metal.

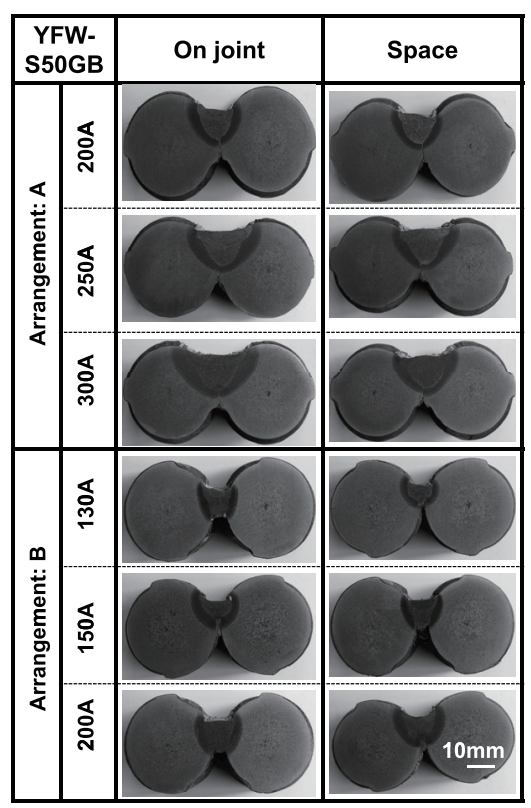

Fig. 7 Cross sectional macrostructures of flare joint of concrete rebar by non-gas arc welding with YFW-S50GB wire.
り, 高電流值になると著しい溶落ちが発生しやすくなると 考えられる．鉄筋配置 B では，溶け达み量も小さく，スパ ッ夕の発生も多く見られた。また, 電流值 $200 \mathrm{~A}$ ではビー ド中央に梨型ビード割れ（図中矢印）が認められ，良好な 溶接結果は得られなかった。これは，マグアーク溶接では アークが開先内に集中し，電流值が大きい $200 \mathrm{~A}$ では，い わゆる梨型状溶け込み形状 ${ }^{10}$ を呈したためと考えられる.

\subsection{3 セルフシールドアーク溶接（亜鉛めっき用ワイヤ YFW-S50GB)}

Fig. 7に亜鉛めっき用ワイヤ（YFW-S50GB）溶接継手の 断面マクロ写真を示す。溶接条件等は軟鋼用ワイヤ

（YGW12）と同様である。このワイヤは，セルフシールド である ${ }^{11)}$. いずれの鉄筋配置でも，電流值にかかわらず良 好なビード外観が得られた。また，溶落ちも認められなか ったことからソリッドワイヤに比してアーク圧力が小さい のではないかと考えられる.

\section{2 溶接欠陥}

\subsection{1 空洞欠陥}

これまでの断面マクロ観察結果から，検討した 5 種類の 半自動アーク溶接では，被覆アーク溶接時に見られるよう な亜鉛蒸気の巻き込みにより形成される空洞は，いずれの 溶接手法でも認められなかった。このことは，被覆アーク 溶接と比較すると，半自動アーク溶接では溶接時のアーク の集中度が大きく，その結果として，電極ワイヤ端のアー ク力が大きくなり, 溶融池が開先下方に押し下げられて, 開先内でアークが発生するのではないかと考えている。こ の結果，亜鉛めっきが直接的にアークにさらされて蒸発 し，鉄筋配置 A では溶融池表側に，ルート間隔が大きい鉄 筋配置 B では，溶融池裏側のルート開口部から噴出したの ではないかと推察される。その状況を，模式的に Fig. 8 に 示す.

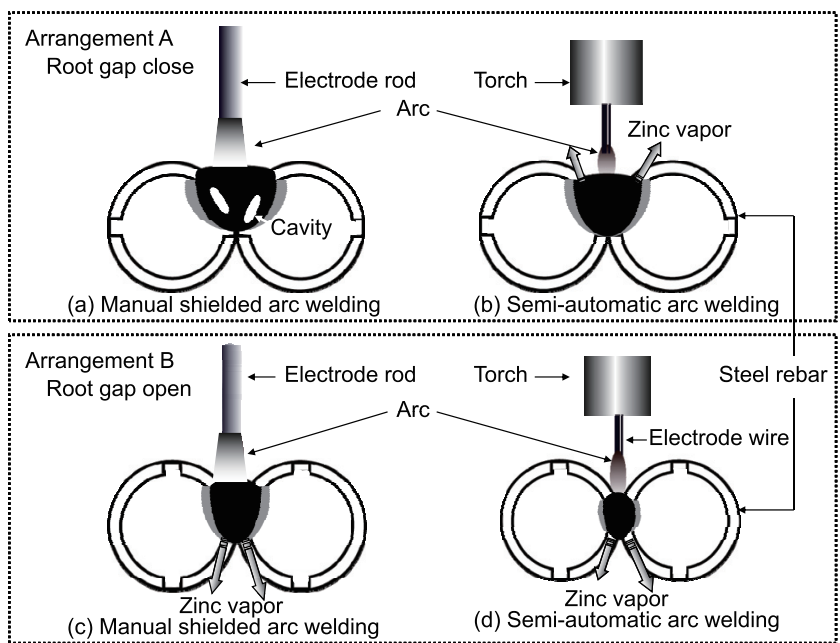

Fig. 8 Image chart of cross section on space of weld joint showing the difference in weld bead formation with arc welding process and rebar joint arrangement. 


\subsection{2 ビード内部の割れ}

Fig. 9 に 5 種類の異なる半自動アーク溶接による溶接継手 部のビード幅 $\mathrm{W}$ と溶け込み深さ $\mathrm{H}$ との比 $(\mathrm{W} / \mathrm{H})$ と電流值 との関係を示す。これらの值は, Fig. 10 に示すように溶接

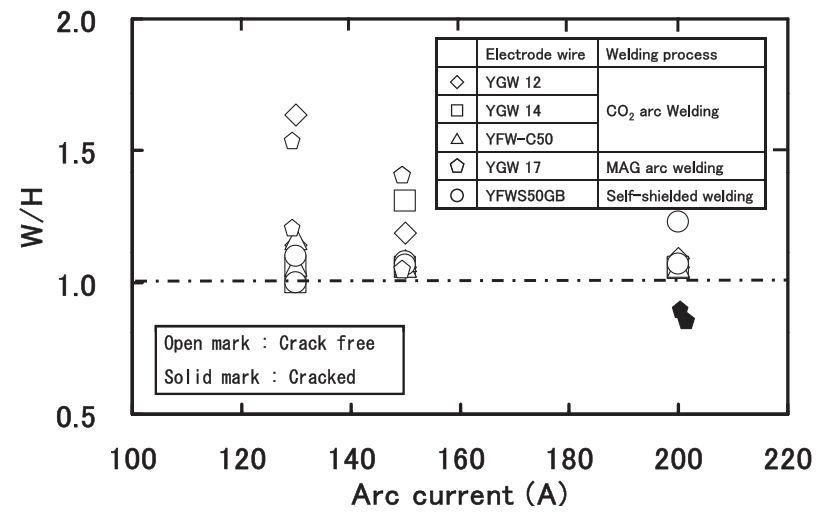

Fig. 9 Relation between $\mathrm{W} / \mathrm{H}$ and arc current at different arc welding processes.

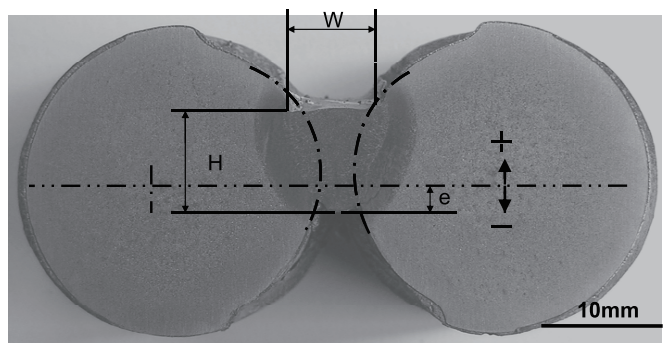

Fig. 10 Definition of weld bead width $\mathrm{W}$, penetration depth $\mathrm{H}$ and partially melt-through width e on cross sectional photo of welded joint.

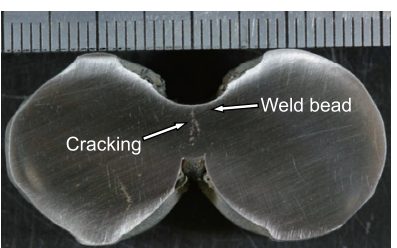

(a) Cracking

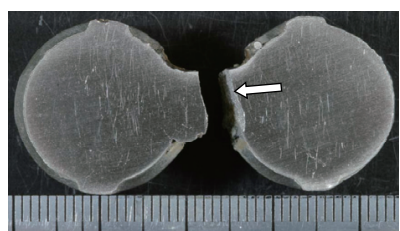

(b) After artificial fracture.

Fig. 11 Cross sectional macrostructures of flare joint of concrete rebar; (a) Cracking in weld bead, (b) After artificial fracture of (a).
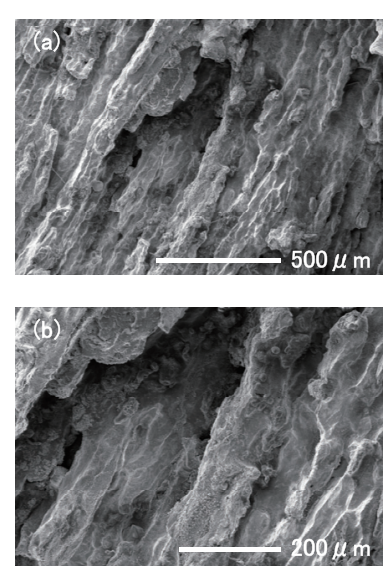

Fig. 12 Fracture surface of weld bead crack showing typical dendritic pattern; (a) and (c) or (b) and (d) show the matching surfaces of crack, respectively.
継手部断面マクロ写真上にて測定した。なお，測定は 5 断 面で行い, その平均值を求めた。 また，図中 e はフレアー 溶接される鉄筋相互の中心線からビード下端までの距離を 示し，中心線より上方を正 (+)，下方を負 (-) とした。負側 の数值が大きくなるほど溶接ビードが下方に押下げられ， 溶落ち傾向にあることを表す。電流值の増加とともに W/H は平均的に減少する傾向を示すが，これはすでに述べたア ーク力の増加によるものと考えられる。一般にアーク力は 電流值の 2 乗に比例すると言われている ${ }^{10)}$.これまでに示 した溶接部断面マクロ観察結果から，ビード内部に割れが 認められたのは（図中黒塗），W/H の值が 1 よりも小さい 場合である。一般的に W/H が 1 以下で梨型ビード割れと呼 ばれる凝固割れが発生しやすいことが報告されている ${ }^{12)}$. さらに，この割れのマクロ観察結果および破面の走査型電 子顕微鏡観察結果を Fig. 11 および Fig. 12 に示す. Fig. 12 の (a) と (c) および (b) と (d) は，それぞれ Fig. 11 (b) の割れ のほほ相対する破面を示す。これより凝固割れに特徴的な セル樹枝状の突起が認められ，これらの割れは凝固割れと 考えられる。これらのことから，ビード中央部における割れ は, 溶接中に発生する凝固割れであり, 溶け込み形状が主要 発生因子である，いわゆる梨型ビード割れと判断される.

\subsection{3 ルート部周辺の融合不良}

Fig. 13 (a) の溶接継手断面写真で見られるように，マクロ 観察結果から溶接ビード下部のルート部とビード溶け落ち 部との間に融合不良と思われる欠陥が認められた。Fig. 14

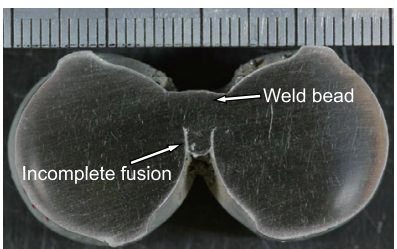

(a) Incomplete fusion

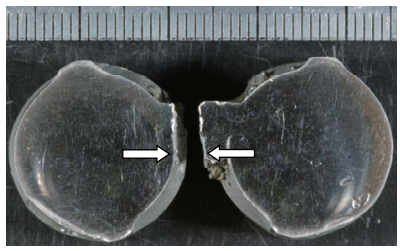

(b) After artificial fracture.
Fig. 13 Cross sectional macrostructures of flare joint of concrete rebar; (a) Incomplete fusion, (b) After artificial fracture of (a).

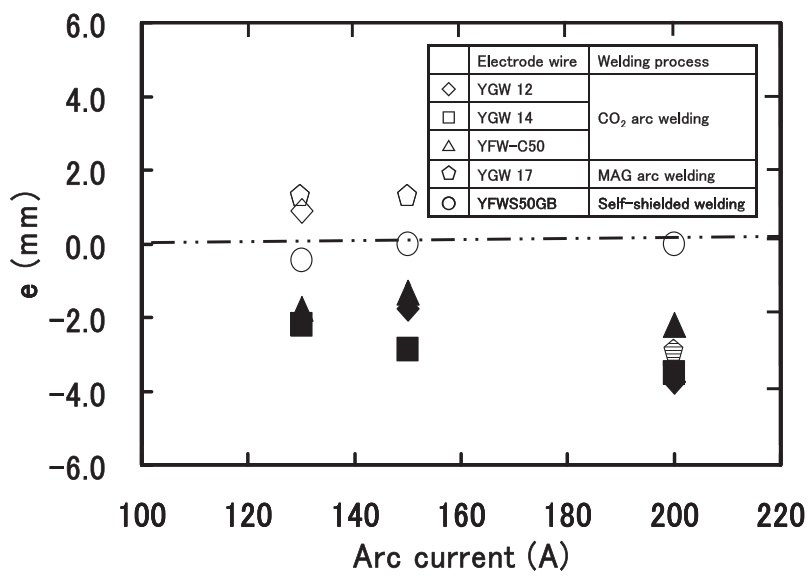

Fig. 14 Relation between index e and arc current at different arc welding processes;open,black and gray marks show defect free, incomplete fusion and cracking, respectively. 
は本研究で実施した 5 種類の半自動アーク溶接部断面にお いて Fig. 10 に示すように測定した部分溶け落ち距離と電流 值の関係を示す。図中で黒印は周辺部の融合不良が発生し た場合を示し，また，横縞の印は上述した梨型ビード割れ を示す.この図から, フレアー溶接される鉄筋相互の中心 線からビード下端までの距離 (e) が-1 mm より小さくなる場 合にルート周辺に融合不良が認められた。さらに，Fig. 13 (b)において矢印で示した融合不良の破面を走査型電子顕微 鏡で観察した結果を Fig. 15 に示す. (a) と (c) の波線で示し た部分は，それぞれ相対する破断面の融合不良面を示し， それ以外の部分は強制破断面である。(b) と (d) は融合不良 面の拡大写真を示す。これから, 破断面はコールドジョイ ント特有な平坦面であり, その表面では凝固割れに特有の デンドライト模様や低温割れの粒内壁開割れなどの特徵は 認められなかった。これらのことから, 溶融金属が下方に 押し出されたことによって，溶接金属と鉄筋との境界部 （開先面）に融合不良が発生したと考える.
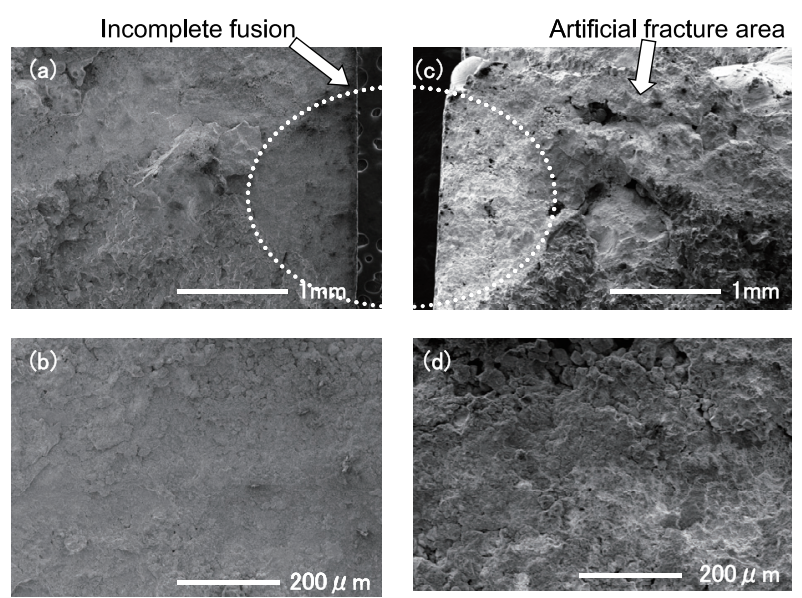

Fig. 15 Fracture surface of weld bead after artificial fracture; (a) and (c) show the matching fracture surface, and (b) and (d) show their magnification photos, respectively.

Table 3 Weldability of the combination of welding wire and arc welding process on flare joint welding of $\mathrm{Zn}$ coated concrete rebar.

\begin{tabular}{|c|c|c|c|c|c|}
\hline Arc welding process & \multicolumn{3}{|c|}{$\mathrm{CO}_{2}$ arc welding } & \multirow{2}{*}{$\begin{array}{c}\begin{array}{c}\text { MAG } \\
\text { arc } \\
\text { welding }\end{array} \\
\text { YGW17 } \\
\end{array}$} & \multirow{2}{*}{$\begin{array}{c}\text { Self-shielded } \\
\text { arc welding }\end{array}$} \\
\hline Standard & YGW12 & YGW14 & YFW-C50 & & \\
\hline (1) Stability of arc & $x$ & $x$ & 0 & $x$ & 0 \\
\hline (2) Generation of spatter & $x$ & $x$ & 0 & $x$ & 0 \\
\hline (3) Crater crack & 0 & 0 & 0 & 0 & 0 \\
\hline (4) Bead crack & 0 & 0 & 0 & $x * B$ & 0 \\
\hline (5) Incomplete fusion & $x * B$ & $x^{*} B$ & $x^{*} B$ & 0 & 0 \\
\hline (6) Undercut & 0 & 0 & 0 & 0 & 0 \\
\hline (7) Incomplete penetration & 0 & $x * B$ & $x{ }^{*} B$ & 0 & $x{ }^{*} B$ \\
\hline (8) Underfill & $x$ & $x$ & $x$ & $x$ & $x$ \\
\hline (9) Melt-through & 0 & 0 & 0 & $x^{*} A$ & 0 \\
\hline (11) Cavity & $\mathrm{O}$ & $\mathrm{O}$ & 0 & $\mathrm{O}$ & O \\
\hline \multicolumn{6}{|c|}{ O: Stable } \\
\hline \multicolumn{2}{|c|}{ (2) Generation of spatter or slag } & :Small amou & \multicolumn{3}{|c|}{$x$ :Large amount } \\
\hline \multicolumn{2}{|l|}{ (3)(4)(5)(6)(7) Weld defect } & O:Absence & \multicolumn{3}{|c|}{$x$ : Existence $>10 \%$} \\
\hline \multicolumn{2}{|l|}{ (8) Underfill >25\% } & O:Absence & \multicolumn{3}{|c|}{$\mathrm{x}$ :Existence } \\
\hline \multicolumn{2}{|l|}{ (9) Melt-through } & O:Absence & \multicolumn{3}{|c|}{$x$ :Existence } \\
\hline \multicolumn{2}{|l|}{ (11) Cavity >5\% } & O:Absence & \multicolumn{3}{|c|}{$x$ :Existence } \\
\hline
\end{tabular}

\section{3 溶接作業性}

Table 3 に本研究で得られた 5 種類の半自動アーク溶接に よる亜鉛めっき鉄筋のフレアー継手溶接の作業性および溶 接欠陷発生状況を定性的にまとめて示す。アークの安定性 およびスパッ夕の発生状況から，亜鉛めっき用ワイヤ （YFW-S50GB）を用いたセルフシールドアーク溶接が最も 良い結果となった。この理由として，このワイヤがセルフ シールドのため, ガスシールドアーク溶接である炭酸ガス アーク溶接及びマグアーク溶接に比してアーク力が小さ く, 溶融池が開先上部に安定的に形成されるためと考えら れる。一方，軟鋼用ワイヤ（YGW12）は，アーク安定性お よびスパッタ, スラグの発生状況から, 他の溶接法と比較す ると劣っていることがわかった。なお，アークの安定性お よびスパッ夕の発生は目視によって確認したものである.

\section{4 フレアー溶接継手強度特性}

Fig. 16 に溶込み深さ（のど厚）とせん断引張試験との関 係を示す。なお，図中の添え字は電流值を示す。この図か ら，溶接法にかかわらずせん断引張破断荷重は，のど厚が 大きくなるにしたがって，増加する傾向を示すことが確認 された。なお，溶接欠陥の影響から，同一のど厚であって

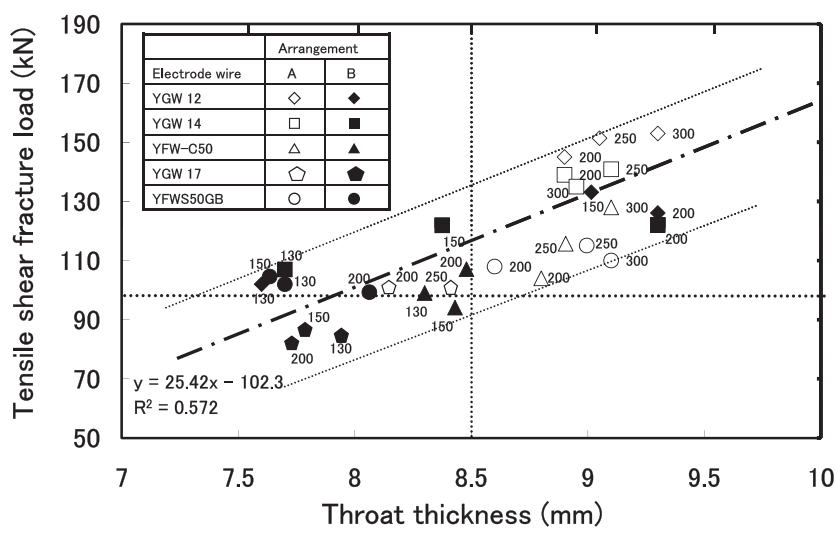

Fig.16 Relation between tensile shear fracture strength and throat thickness at different arrangements by five kinds of welding processes.

Table 4 Evaluation result of weldability of welding wire and arc welding process on flare joint welding of $\mathrm{Zn}$ coated concrete rebar.

\begin{tabular}{|c|c|c|c|c|c|c|}
\hline & \multirow[b]{2}{*}{$\begin{array}{l}\text { Current } \\
\text { (A) }\end{array}$} & \multicolumn{3}{|c|}{$\mathrm{CO}_{2}$ arc welding } & \multirow{2}{*}{$\begin{array}{c}\begin{array}{c}\text { MAG arc } \\
\text { welding }\end{array} \\
\text { YGW17 }\end{array}$} & \multirow{2}{*}{$\begin{array}{c}\begin{array}{c}\text { Self- } \\
\text { shielded arc } \\
\text { welding }\end{array} \\
\text { YFW-S50GE }\end{array}$} \\
\hline & & YGW12 & YGW14 & YFW-C50 & & \\
\hline \multirow{3}{*}{$\begin{array}{c}\text { Arrangement } \\
\text { A }\end{array}$} & 200 & $\mathrm{O}$ & $\mathrm{O}$ & $\Delta$ & $\Delta$ & O \\
\hline & 250 & $\mathrm{O}$ & $\mathrm{O}$ & 0 & $\Delta$ & 0 \\
\hline & 300 & 0 & $\mathrm{O}$ & $\mathrm{O}$ & $x$ & $\mathrm{O}$ \\
\hline \multirow{3}{*}{$\begin{array}{c}\text { Arrangement } \\
\text { B }\end{array}$} & 130 & $\Delta$ & $\Delta$ & $\Delta$ & $x$ & $\Delta$ \\
\hline & 150 & $\mathrm{O}$ & $\Delta$ & $\Delta$ & $x$ & $\Delta$ \\
\hline & 200 & 0 & 0 & $\Delta$ & $x$ & $\Delta$ \\
\hline \multicolumn{2}{|c|}{ Welding operation } & Bad & Bad & Good & Bad & Good \\
\hline
\end{tabular}

$\mathrm{O}$ : Throat thickness $>8.5 \mathrm{~mm}$ and Shear loading $>100 \mathrm{kN}$

$\Delta$ : Throat thickness $<8.5 \mathrm{~mm}$ and Shear loading $>100 \mathrm{kN}$

$\square$ :Throat thickness $>8.5 \mathrm{~mm}$ and Shear loading $<100 \mathrm{kN}$

$x$ :Throat thickness $<8.5 \mathrm{~mm}$ and Shear loading $<100 \mathrm{kN}$ 
も破断荷重に変動が認められた。鉄筋フレアー溶接継手の 場合, 主に継手の良否はのど厚とせん断引張荷重の結果か ら判断されている ${ }^{13)}$. 本研究で検討した半自動アーク溶接 においては，鉄筋継手に必要とされる荷重 $100 \mathrm{kN}$ を分に 満足するには，のど厚は $8.5 \mathrm{~mm}$ が必要であると判断され る. Table 4 に溶込み深さの結果とせん断引張試験結果を溶 接方法（溶接ワイヤ）ごとにまとめた表を示す。この表か ら，鉄筋配置 A（開先ギャップなし）では，覀鉛めっき用 ワイヤ（YGW17）を用いた炭酸ガスアーク溶接以外の試料 は，良好な継手が得られることがわかった。被覆アーク溶 接法では，亜鉛蒸気の溶接ビード内への巻き込みによる空 洞を排除するためには，鉄筋配置 $\mathrm{B}$ (開先ギャップあり） で行なう方が良い結果が得られたが，半自動アーク溶接の 場合では逆の結果となった。すなわち，被覆アーク溶接法 では良い結果が得られた鉄筋配置 B に対して，半自動アー ク溶接では，一部の場合を除いて，良好な結果は得られな かった。

\section{4. 結言}

本研究では，溶融亜鉛めっき鋼板溶接用として市販され ている溶接材料を含む 5 種類の溶接ワイヤを用いて溶融亜 鉛めっき鉄筋フレアー溶接継手への半自動アーク溶接（炭 酸ガスアーク溶接, マグアーク溶接, セルフシールドアー ク溶接）の適用性を検討した。得られた主な結果は以下の とおりである。

1）開先内でリブが突き合わされてルート間隔がない鉄筋配 置 $\mathrm{A}$ に比べて, リブが開先内になくルート間隔が大き い鉄筋配置 B での同一電流值では，溶接ワイヤ/溶接プ ロセスの組み合わせに依らず溶落ちが発生しやすい。

2）被覆アーク溶接による溶融亜鉛めっき鉄筋フレアー継手 で発生した亜鉛蒸気の溶接ビード内への巻き込みによる 空洞は，検討した半自動アーク溶接では鉄筋配置によら ず発生しなかった。

3）鉄筋フレアー溶接継手強度の評価結果から，半自動アー ク溶接では鉄筋配置 $\mathrm{A}$ ，すなわち，お互いのリブが突き 合わされた開先を用いた溶接が適している。

4）鉄筋配置 $\mathrm{A}$ を用いると，軟鋼用ワイヤ (YGW12)/炭酸 ガスアーク溶接，覀鉛めっき用ワイヤ（YGW14）/炭酸 ガスアーク溶接および亜鉛めっき用ワイヤ（YFWS50GB)/セルフシールドアーク溶接の組み合わせによる
半自動アーク溶接は適正な溶接条件下では，溶融亜鉛め つき継手への適用は鉄筋継手強度の観点から可能と判断 される。

5）覀鉛めっき用ワイヤ（YFW-S50GB）/セルフシールドガ スアーク溶接の組み合わせでは，その他のワイヤ/溶接 プロセスの組み合わせで見られたスパッタの多量飛散に よるシールドノズル閉塞によって引き起こされるアーク の不安定さが低減される傾向を示し，本研究で評価した 半自動アーク溶接では最も良好な適用性を示す結果が得 られた。

$$
\text { 謝辞 }
$$

本報告は，平成22年度に大阪大学接合科学研究所「接合 科学共同利用・共同研究拠点」共同研究員制度を利用した 成果の一部である。

\section{参 考 文 献}

1) K. Fukui, T. Kou and M. Utihara: 表面処理鋼板の溶接性, Sumitomo Met, 145 (1993), 56

2) P. C. Porter: 構造用鋼材の亜鉛めっきと溶接，Lead \& Zinc, 122 (1984), 47.

3) H. Matsui, H. Suzuki, M, Yamada, T. Hattori and T. Shinoya: 溶融 亜鉛めっき鋼板へのアーク溶接の適用, Yoyota Tech Rev, 145 (1995), 116.

4) H. Matsui and M. Yamada: 溶融亜鉛めっき薄鋼板のアーク施工 法に関する基礎検討， Q. J. Jpn. Weld. Soc, 15 (1997), 484.

5) 松井仁志：重称合わせアーク溶接方法，日本国特許公開，昭 和 62-179869 号公報。

6) K. Murakami, N. Maeda, H. Kanematsu and K. Nakata: 溶融亜鉛 めっき鉄筋の被覆アーク溶接性に及ぼす鉄筋配置の影響, $\mathrm{Q}$. J. Jpn. Weld. Soc, 25 (2007), 128.

7) 平井宏樹：亜鉛めっき鋼板用溶接ワイヤの開発，電気製鋼， 67-3 (1996), 221-227.

8）梅原悠，鈴木励一，中野利彦：薄鋼板用アーク溶接ワイヤ $\lceil$ SEA-50FS 」，KOBE STEEL ENGINEERING REPORTS, 57-2 (2007), 90-94.

9) 大同特殊鋼製品総合カタログ：ソリッドワイヤ，亜鉛メッキ 鋼 (2007), 27.

10）日本溶接協会編：溶接実務入門-手溶接からロボットまで-, 産報出版，(2002), 216.

11）ニッコー熔材製品総合カタログ：フラックス入りワイヤ (2002), 75

12）溶接アーク物理研究委員会：溶接プロセスの物理 (1996), 49 .

13）土木学会：コンクリート標準示方書 施工編 (2007), 141. 